\title{
UDC 539.3
}

\section{SPLINE COLLOCATION METHOD FOR FREE VIBRATION ANALYSIS OF LAMINATED SHALLOW SHELLS}

\author{
Oleg Pavlenko
}

\section{Ternopil Ivan Pul'uj National Technical University, Ternopil, Ukraine}

\begin{abstract}
Summary. The presented study deals with free vibration of cross-ply symmetrically laminated composite doubly-curved panels with constant thickness. Based on the first-order shear deformation theory (FSDT) the equations of motion are derived by applying the Hamilton's principle. Spline function approximation technique, which includes B-splines of the third order, is used to reduce two-dimensional system of coupled differential equations in terms of displacement and rotational functions to one-dimensional. A generalized eigenvalue problem is obtained by applying a point collocation method with suitable boundary conditions. The vector-matrix form of the governing equations with different boundary conditions, from which values of a frequency parameter is obtained, is presented. These systems of ordinary differential equations are solved using the Godunov's discrete orthogonalization method. The effects of curvature ratio and thickness-to-length ratio on the fundamental natural frequencies of composite doubly-curved panels with all sides simply supported are investigated. In order to verify the accuracy of the employed method the frequency parameters are evaluated in comparison with the previous paper available in the literature. Good agreement with other available data demonstrates the capability and reliability of the spline collocation method and the adopted composite doubly-curved shell model used.
\end{abstract}

Key words: free vibration, laminated shallow shell, spline collocation method, Mindlin theory.

Received 22.05.2018

Statement of the problem. Laminated shells are widely applied in many branches of modern engineering, construction, ship, plane and rocket engineering in particular. Such systems being under operation are subjected to different dynamic loads, which can cause dangerous vibrations of both the elements and the whole structure. To design the shell structure for effective enduring of static and dynamic loads, it is necessary to determine the conditions of its strength and reliability. To analyze the strength and bearing capacity of laminated shells it is necessary to know the factors of the stress-strain state, as well as the rate of their change in time. Hence there arises a need to develop optimal and accurate enough approaches to the mathematic, geometric and computer modeling of the dynamics problems of laminated shells with subsequent solving them by precise and effective methods.

Analysis of the available investigation results. The developments, analysis and classification of many available theories of laminated plates and shells are presented in the review [1]. The articles [2,3] deal with the putting in order the latest achievements of the dynamic behavior of laminated composites. The papers by G.M. Hryhorenko and his colleagues $[4,6]$ are devoted to many important problems of analysis of the laminated plates and shells of different geometry in classical and refined statements by the variation, numerical and numerical-analytical methods. A great number of static and dynamic problems of laminated composite shells and plates are solved in monographs [7 - 9]. P.K. Mallick [7] has studied the dynamic characteristics of composite plates and shells. M.S. Qatu [8] described the dynamic behavior of the laminated plates and shallow shells. J.N. Reddy [9] has focused on the analysis of both real examples and the general mechanics of plates and shells.

The objective of the paper is to investigate the effect of geometric and mechanical characteristics on the natural frequencies of the laminated shallow shells, taking advantage of the spline collocation method to obtain the system of ordinary differential equations and use 
the discrete orthogonalization technique for its solution as well as to specify the expediency of this approach for the solution of certain dynamics problems.

Statement of the task. In order to investigate the free vibrations of cross-ply symmetrically laminated doubly-curved shallow shells with constant thickness, made of specially orthotropic material, the first-order shear deformation theory (FSDT) is engaged. For the specially orthotropic material, according to [4-6,9], it is considered, that the main elasticity directions of each layer coincide with the coordinate lines, and the main assumptions of the elasticity theory of the homogeneous orthotropic body are true for every layer of the shell: within each layer the continuity hypothesis, which ignores the atomistic structure, is expected to be true; the conditions of the ideal layer bonds, related to the lack of separation and mutual skidding on the contact surface, are assumed; the material of every layer is considered to be orthotropic, linear-elastic and being subject to the generalized Hooke's law.

For the reinforced layer it is expected, that the bond between matrix and the fibres is ideal; the fibres are parallel and uniformly distributed; the matrix has neither pores nor cracks and is under non-stressed initial state; the applied loads are either parallel or perpendicular to the fibres direction.

From now on we choose the mid-surface of the shell as a coordinate plane and assume deformations to be small. For the layer package the Mindline-type theory is considered to be true, according to which, two following hypothesis are introduced. The straight line hypothesis (kinematic) - normal to the shell mid-surface rectilinear element before deformation keeps its length and remains straight but not necessarily normal to the shell mid-surface after deformation. The static hypothesis: normal stresses on the planes parallel to the mid-surface are negligible in comparison with the ones on the planes perpendicular to it.

Besides, the inertia forces caused by the displacement of the mid-surface element and rotation of the normal elements are taken into account. The temperature and piezo-electric effects are absent. Also, the coefficient of the elastic basis is of the Vinckler type $K_{p}=0$.

There are different approaches for panels and shallow shells classification depending on the relation between their minimum geometric size and thickness. In our paper let us assume [8] $a_{\text {min }} / h>50$ - embrane, $20<a_{\min } / h \leq 50 \Pi$ - thin, $10<a_{\min } / h \leq 20$ - moderately thick, $a_{\min } / h \leq 10-$ thick.

General equations of the shell theory must be used while analyzing deep shallow shells. But, in the case of sufficient shallowness $R_{\min } / a_{\max } \geq 2$, the following additional assumptions make the initial system of equations easier, without the decrease in accuracy.

The shell is projected on the plane as the rectangle with sides $a$ and $b$. Thus, instead of the curvilinear coordinate system the Cartesian one is used, its geometry being similar to that of the plate (the Lame' parameters $A=B=1$ )

The curvature changes caused by the tangential displacement components $u$ and $v$ are small, in comparison with changes caused by the normal component $w$. Also, the transverse shear forces are much smaller then the term $R_{i}\left(\partial N_{i} / \partial i\right): u_{i} / R_{i}<<1, \quad Q_{i}<<R_{i}\left(\partial N_{i} / \partial i\right)$, $\left(1+z / R_{i}\right) \approx 1$, where $u_{i}$ is $u$ or $v, Q_{i}$ is $Q_{x}$ or $Q_{y}, N_{i}$ is $N_{x}, N_{y}$ or $N_{x y}$ and $R_{i}$ is $R_{x}$ or $R_{y}$. The term $(\partial i)$ indicates derivative with respect to either $x$ or $y$.

The real distribution of transverse shear strains is non-linear through the laminate thickness, it follows that transverse shear stresses vary through the laminate thickness. Moreover, the introduced kinematic hypothesis does not provide the condition of vanishing of transverse shear stresses on the top and bottom of a general laminate composed of monoclinic layers. That is why there arises a need to introduce the shear correction coefficient $K$, which is found from the condition of sequence of two assumptions introduced independently from 
each other as to the nature of the displacements and transverse stresses distribution along the shell thickness. In this paper the shear correction factor is assumed to be $K=5 / 6$.

The introduced hypotheses make it possible to analyze the two-dimensional problem of its mid-surface vibration instead of the three-dimensional dynamics problem of the shell as the spatial body, and the assumptions as to the geometry make it possible to present the characteristics in the orthogonal coordinate system.

Let us present free vibration relations for the analyzed shells. According to the FSDT, kinematic and deformation factors of the three-dimensional theory of elasticity are connected to the corresponding factors of the employed one as follows:

$$
\begin{array}{ll}
u_{x}(x, y, z, t)=u(x, y, t)+z \psi_{x}, & e_{x}(x, y, z, t) \approx \varepsilon_{x}(x, y, t)+z \chi_{x}(x, y, t), \\
u_{y}(x, y, z, t)=v(x, y, t)+z \psi_{y}, & e_{y}(x, y, z, t) \approx \varepsilon_{y}(x, y, t)+z \chi_{y}(x, y, t), \\
u_{z}(x, y, z, t)=w(x, y, t), & e_{x y}(x, y, z, t) \approx \varepsilon_{x y}(x, y, t)+2 z \chi_{x y}(x, y, t), \\
\psi_{x}=\left.\frac{\partial u_{x}}{\partial z}\right|_{z=0}, \quad \psi_{y}=\left.\frac{\partial u_{y}}{\partial z}\right|_{z=0}, & e_{x z}(x, y, z, t) \approx \gamma_{x}(x, y, t), \\
e_{y z}(x, y, z, t) \approx \gamma_{y}(x, y, t) .
\end{array}
$$

The strain-displacement relations take the form

$$
\begin{array}{llll}
\mathcal{E}_{x}=\frac{\partial u}{\partial x}+k_{1} w, & \varepsilon_{y}=\frac{\partial v}{\partial y}+k_{2} w, & \varepsilon_{x y}=\frac{\partial u}{\partial y}+\frac{\partial v}{\partial x}, & \gamma_{x}=\psi_{x}+\frac{\partial w}{\partial x}-k_{1} u, \\
\chi_{x}=\frac{\partial \psi_{x}}{\partial x}-k_{1}^{2} w, & \chi_{y}=\frac{\partial \psi_{y}}{\partial y}-k_{2}^{2} w, & 2 \chi_{x y}=\frac{\partial \psi_{x}}{\partial y}+\frac{\partial \psi_{y}}{\partial x}, & \gamma_{y}=\psi_{y}+\frac{\partial w}{\partial y}-k_{2} v .
\end{array}
$$

In the expressions (1), (2) $u(x, y, t), v(x, y, t)$ - tangential and $w(x, y, t)$ - normal displacement of a point on the mid-surface; $\varepsilon_{x}, \varepsilon_{y}, \varepsilon_{x y}$ - mid-surface normal strains; $\chi_{x}, \chi_{y}$, $2 \chi_{x y}$ - bending strains; $\psi_{x}, \psi_{y}$ - total rotations of a transverse normal about the $y-$ and $x-$ axes, respectively; $\gamma_{x}, \gamma_{y}$ - transverse shear strains; $k_{1}=1 / R_{x}, k_{2}=1 / R_{y}$ - curvatures; $R_{x}$, $R_{y}$ - radii of curvature in the $x$ and $y$ directions, respectively. Note, that for the spherical shallow shells the curvatures $k_{1}=k_{2}=1 / R$, and for the parabolic ones $-k_{1}=0, k_{2}=1 / R$.

Using Hamilton's principle yields the following equations of motion:

$$
\begin{gathered}
\frac{\partial N_{x}}{\partial x}+\frac{\partial N_{y x}}{\partial y}=I_{0} \frac{\partial^{2} u}{\partial t^{2}}+I_{1} \frac{\partial^{2} \psi_{x}}{\partial t^{2}}, \frac{\partial M_{x}}{\partial x}+\frac{\partial M_{y x}}{\partial y}-Q_{x}=I_{1} \frac{\partial^{2} u}{\partial t^{2}}+I_{2} \frac{\partial^{2} \psi_{x}}{\partial t^{2}} \\
\frac{\partial N_{y}}{\partial y}+\frac{\partial N_{x y}}{\partial x}=I_{0} \frac{\partial^{2} v}{\partial t^{2}}+I_{1} \frac{\partial^{2} \psi_{y}}{\partial t^{2}}, \frac{\partial M_{y}}{\partial y}+\frac{\partial M_{x y}}{\partial x}-Q_{y}=I_{1} \frac{\partial^{2} v}{\partial t^{2}}+I_{2} \frac{\partial^{2} \psi_{y}}{\partial t^{2}} \\
\frac{\partial Q_{x}}{\partial x}+\frac{\partial Q_{y}}{\partial y}-k_{1} N_{x}-k_{2} N_{y}=I_{0} \frac{\partial^{2} w}{\partial t^{2}} .
\end{gathered}
$$

It is necessary to account for the vanishing of the moments about the normal to the shell element in the formulation, otherwise, it will lead to inconsistency associated with rigid body rotations. That said, an additional relation must be introduced

$$
N_{x y}-k_{2} M_{y x}-N_{y x}+k_{1} M_{x y}=0 .
$$


In the equations (3) and (4) force and moment resultants in the cross-section $x=$ const $N_{x}, N_{x y}, Q_{x}, M_{x}, M_{x y}$ have dimensions of force and moment per unit of the arch length $x=$ const, respectively, and are considered to be statically equal to the stresses acting in the normal cross-section of the shell perpendicular to the direction $y$. The resultants have the following interpretation: $N_{x}$ - normal force, $N_{x y}$-in-plane shear force, $Q_{x}$-transverse shear force, $M_{x}$ - bending moment, $M_{x y}$ - twisting moment. Force and moment resultants in the cross-section $y=$ const $N_{y}, N_{y x}, Q_{y}, M_{y}, M_{y x}$ are of similar nature.

The inertia moments $I_{0}, I_{1}, I_{2}$ of the normal element rotation about the axes $x$ and $y$, taking into account the laminated structure of the shell, are expressed as follows:

$$
I_{j}=\sum_{i=1}^{M} \int_{z_{i-1}}^{z_{i}} \rho^{i} z^{j} d z \quad(j=0,1,2) .
$$

In (5) $M$ - number of layers, $\rho^{i}=\rho^{i}(x, y, z)-$ density, $z=z_{i-1}(x, y), z=z_{i}(x, y)-$ the boundary surfaces equation. In our case we have

$$
I_{0}=\rho h, \quad I_{1}=0, \quad I_{2}=\frac{\rho h^{3}}{12} .
$$

The constitutive equations that relate the force and moment resultants to the strains of the laminate are given by

$$
\begin{array}{lll}
N_{x}=C_{11} \varepsilon_{x}+C_{12} \varepsilon_{y}, & N_{y}=C_{12} \varepsilon_{x}+C_{22} \varepsilon_{y}, & Q_{x}=K C_{55} \gamma_{x}, \\
N_{x y}=C_{66} \varepsilon_{x y}+2 k_{2} D_{66} \chi_{x y}, & N_{y x}=C_{66} \varepsilon_{x y}+2 k_{1} D_{66} \chi_{x y}, & Q_{y}=K C_{44} \gamma_{y} \\
M_{x}=D_{11} \chi_{x}+D_{12} \chi_{y}, & M_{y}=D_{12} \chi_{x}+D_{22} \chi_{y}, & M_{x y}=M_{y x}=2 D_{66} \chi_{x y} .
\end{array}
$$

In the expressions (7) the coefficients are called $C_{m n}$ extensional stiffness, $D_{m n}$ bending stiffness, $K_{m n}$ bending-extensional coupling stiffness [6,9] and interpreted as follows. $C_{11}$ and $C_{22}$ - stiffness of stretching-compression along the coordinate lines $y=$ const and $x=$ const. $C_{44}, C_{45}, C_{55}, C_{66}$ - shear stiffness in the tangential to the mid-surface plane. $C_{16}$ and $C_{26}-$ accompanying stiffness of stretching-compression and shear, specifying the effect of elongation along the coordinate lines $y=$ const and $x=$ const on the shear in the tangential to the midsurface plane. $K_{11}$ and $K_{22}$ - stiffness of tension and bending mutual effect along the lines $y=$ const and $x$ =const. $K_{16}$ and $K_{26}$-accompanying stiffness of the mutual effect of bending on shear and elongation on torsion. $K_{66}$-stiffness of torsion and shear mutual effect. $D_{11}$ and $D_{22}$ - stiffness of bending about the axes tangential to the coordinate lines $x=$ const and $y=$ const. $D_{16}$ and $D_{26}$-accompanying stiffness of bending and torsion, specifying the effect of bending about the axes tangential to the lines $x=$ const and $y=$ const on torsion. $D_{66}-$ torsion stiffness.

Laminate stiffness depends on the mechanical parameters and the thickness of layers: 


$$
C_{m n}=\sum_{i=1}^{M} \int_{z_{i-1}}^{z_{i}} \bar{B}_{m n}^{i} d z, \quad K_{m n}=\sum_{i=1}^{M} \int_{z_{i-1}}^{z_{i}} \bar{B}_{m n}^{i} z d z, \quad D_{m n}=\sum_{i=1}^{M} \int_{z_{i-1}}^{z_{i}} \bar{B}_{m n}^{i} z^{2} d z
$$

Stiffness parameters of the $i$-th layer $B_{m n}^{i}$ must be transformed from the material coordinate system to the laminate coordinates as follows:

$$
\begin{aligned}
\bar{B}_{11}^{i} & =B_{11}^{i} \cos ^{4} \theta+2\left(B_{12}^{i}+2 B_{66}^{i}\right) \sin ^{2} \theta \cos ^{2} \theta+B_{22}^{i} \sin ^{4} \theta, \\
\bar{B}_{12}^{i} & =\left(B_{11}^{i}+B_{22}^{i}-4 B_{66}^{i}\right) \sin ^{2} \theta \cos ^{2} \theta+B_{12}^{i}\left(\sin ^{4} \theta+\cos ^{4} \theta\right), \\
\bar{B}_{22}^{i} & =B_{11}^{i} \sin ^{4} \theta+2\left(B_{12}^{i}+2 B_{66}^{i}\right) \sin ^{2} \theta \cos ^{2} \theta+B_{22}^{i} \cos ^{4} \theta, \\
\bar{B}_{16}^{i} & =\left(B_{11}^{i}-B_{12}^{i}-2 B_{66}^{i}\right) \sin \theta \cos ^{3} \theta+\left(B_{12}^{i}-B_{22}^{i}+2 B_{66}^{i}\right) \sin ^{3} \theta \cos \theta, \\
\bar{B}_{26}^{i} & =\left(B_{11}^{i}-B_{12}^{i}-2 B_{66}^{i}\right) \sin ^{3} \theta \cos \theta+\left(B_{12}^{i}-B_{22}^{i}+2 B_{66}^{i}\right) \sin \theta \cos ^{3} \theta, \\
\bar{B}_{66}^{i} & =\left(B_{11}^{i}+B_{22}^{i}-2 B_{12}^{i}-2 B_{66}^{i}\right) \sin ^{2} \theta \cos ^{2} \theta+B_{66}^{i}\left(\sin ^{4} \theta+\cos ^{4} \theta\right), \\
\bar{B}_{44}^{i}= & B_{44}^{i} \cos ^{2} \theta+B_{55}^{i} \sin ^{2} \theta, \quad \bar{B}_{55}^{i}=B_{55}^{i} \cos ^{2} \theta+B_{44}^{i} \sin ^{2} \theta \\
& \bar{B}_{45}^{i}=\left(B_{55}^{i}-B_{44}^{i}\right) \cos \theta \sin \theta,
\end{aligned}
$$

where $\theta$ - the angle between the layer coordinates and the global coordinate. The coefficients $B_{m n}^{i}$ are known in terms of the engineering constants of the $i$-th layer:

$$
\begin{aligned}
B_{11}^{i}=\frac{E_{x}^{i}}{1-v_{x}^{i} v_{y}^{i}}, & B_{12}^{i}=\frac{v_{y}^{i} E_{x}^{i}}{1-v_{x}^{i} v_{y}^{i}}, & B_{22}^{i}=\frac{E_{y}^{i}}{1-v_{x}^{i} v_{y}^{i}}, \\
B_{44}^{i}=G_{y z}^{i}, & B_{55}^{i}=G_{x z}^{i}, & B_{66}^{i}=G_{x y}^{i} .
\end{aligned}
$$

In formulas (10) $E_{x}^{i}, E_{y}^{i}$ - moduli of elasticity of the $i$-th layer alone $x$ - and $y$-axes, respectively; $v_{x y}^{i}, v_{y x}^{i}$ - major and minor Poisson's ratios of the $i$-th layer, respectively, defined as the ratio of transverse strain in the direction of the second index to the axial strain in the direction of the first index; $G_{x y}^{i}, G_{x z}^{i}, G_{y z}^{i}$ - shear moduli of the $i$-th layer in the plane parallel to the coordinate surface $z=$ const, $y=$ const,$x=$ const, respectively.

Stiffness coefficients of the equations (7) due to $(8-10)$ for $0 / 90 / 90 / 0$ and $0 / 90 / 0$ lamination schemes, respectively, become

$$
\begin{gathered}
C_{11}=C_{22}=\frac{h\left(E_{x}+E_{y}\right)}{2\left(1-v_{x y} v_{y x}\right)}, \quad C_{12}=\frac{v_{y x} E_{x} h}{1-v_{x y} v_{y x}}, \quad C_{66}=G_{x y} h, \\
C_{44}=C_{55}=\frac{h}{2}\left(G_{x z}+G_{y z}\right), \quad D_{11}=\frac{h^{3}\left(7 E_{x}+E_{y}\right)}{96\left(1-v_{x y} v_{y x}\right)}, \quad D_{12}=\frac{v_{y x} E_{x} h^{3}}{12\left(1-v_{x y} v_{y x}\right)}, \\
D_{22}=\frac{h^{3}\left(E_{x}+7 E_{y}\right)}{96\left(1-v_{x y} v_{y x}\right)}, \quad D_{66}=\frac{G_{x y} h^{3}}{4} ;
\end{gathered}
$$




$$
\begin{array}{lll}
C_{11}=\frac{h\left(2 E_{x}+E_{y}\right)}{3\left(1-v_{x y} v_{y x}\right)}, & C_{12}=\frac{v_{y x} E_{x} h}{1-v_{x y} v_{y x}}, & C_{22}=\frac{h\left(E_{x}+2 E_{y}\right)}{3\left(1-v_{x y} v_{y x}\right)}, \\
C_{44}=\frac{h}{3}\left(G_{x z}+2 G_{y z}\right), & C_{55}=\frac{h}{3}\left(2 G_{x z}+G_{y z}\right), & C_{66}=G_{x y} h, \quad D_{66}=\frac{G_{x y} h^{3}}{12}, \\
D_{11}=\frac{h^{3}\left(26 E_{x}+E_{y}\right)}{324\left(1-v_{x y} v_{y x}\right)}, & D_{12}=\frac{v_{y x} E_{x} h^{3}}{12\left(1-v_{x y} v_{y x}\right)}, & D_{22}=\frac{h^{3}\left(E_{x}+26 E_{y}\right)}{324\left(1-v_{x y} v_{y x}\right)} .
\end{array}
$$

In order to solve real problems it is necessary to introduce the boundary conditions for the equations (2) - (6). In accordance with the FSDT, it is necessary to have five conditions on the edges of the mid-surface in terms of primary variables (displacements and rotations) or secondary variables (forces and moments resultants). For the simply supported sides $x=0$, $x=a$ we have

$$
\frac{\partial u}{\partial x}=0, \quad v=w=0, \quad \frac{\partial \psi_{x}}{\partial x}=0, \quad \psi_{y}=0
$$

Similar conditions can be obtained on the sides $y=0, y=b$ by changing $x \rightarrow y$, $u \rightarrow v, \psi_{x} \rightarrow \psi_{y}$ in (13).

As it is known, the initial conditions are not provided directly, but it is assumed, that all points of the elastic body vibrate with the similar frequency so, that the investigated process is specified by the set of harmonic components, which looks like this:

$$
\begin{aligned}
& \left(u(x, y, t) \quad v(x, y, t) \quad w(x, y, t) \quad \psi_{x}(x, y, t) \quad \psi_{y}(x, y, t)\right)^{T}=\bar{F}(x, y) e^{i \omega t}, \\
& \bar{F}(x, y)=\left(\begin{array}{lllll}
U(x, y) & V(x, y) & W(x, y) & \Psi_{x}(x, y) & \Psi_{y}(x, y)
\end{array}\right)^{T} .
\end{aligned}
$$

Note, that the components of the vector $\bar{F}(x, y)$ specify the form corresponding to the frequency of free vibrations $\omega$. Let us make the equations, frequency parameters and boundary conditions nondimensionlalozed by the following means:

$$
x=a X, \quad y=b Y, \quad \varpi=\omega a^{2} \sqrt{\rho / E_{y} h^{2}} .
$$

The equations of motion (3) can be expressed in terms of $U(X, Y), V(X, Y), W(X, Y)$, $\Psi_{X}(X, Y), \Psi_{Y}(X, Y)$ by substituting the force and moment resultants from (7) and taking into account formulas (6), (14) and (15). Received system of coupled partial differential equations with constant coefficients does not contain derivatives of the variable functions with respect to $Y$ above the second order. Thus, B-splines of the third order can be used along $Y$ direction [5] in order to reduce partial differential equations to the ordinary ones. According to the above, the solutions are presented as follows:

$$
\begin{gathered}
U(X, Y)=\sum_{i=0}^{N} u_{i}(X) \varphi_{1 i}(Y), \quad V(X, Y)=\sum_{i=0}^{N} v_{i}(X) \varphi_{2 i}(Y), \quad W(X, Y)=\sum_{i=0}^{N} w_{i}(X) \varphi_{3 i}(Y), \\
\Psi_{X}(X, Y)=\sum_{i=0}^{N} \psi_{X i}(X) \varphi_{4 i}(Y), \quad \Psi_{Y}(X, Y)=\sum_{i=0}^{N} \psi_{Y i}(X) \varphi_{5 i}(Y)
\end{gathered}
$$


where $u_{i}(X), v_{i}(X), w_{i}(X), \psi_{X i}(X), \psi_{Y i}(X)$ - the sought functions of the variable $X ; \varphi_{j i}(Y)$ $(j=\overline{1,5})$ - linear combinations of B-splines of the third order on the uniform lattice $\Delta$ : $0=Y_{0}<Y_{1}<\ldots<Y_{N}=1$, which satisfy the boundary conditions on the sides $Y=0$ and $Y=1$. The functions $\varphi_{j i}(Y)$ are presented as follows:

$$
\begin{gathered}
\quad j=1,4: \\
\left\{\begin{array} { l } 
{ \varphi _ { j 0 } ( Y ) = B _ { 3 } ^ { 0 } ( Y ) ; } \\
{ \varphi _ { j 1 } ( Y ) = B _ { 3 } ^ { - 1 } ( Y ) - \frac { 1 } { 2 } B _ { 3 } ^ { 0 } ( Y ) + B _ { 3 } ^ { 1 } ( Y ) ; } \\
{ \varphi _ { j i } ( Y ) = B _ { 3 } ^ { i } ( Y ) , \quad i = \overline { 2 , N - 2 } ; } \\
{ \varphi _ { j N - 1 } ( Y ) = B _ { 3 } ^ { N - 1 } ( Y ) - \frac { 1 } { 2 } B _ { 3 } ^ { N } ( Y ) + B _ { 3 } ^ { N + 1 } ( Y ) ; } \\
{ \varphi _ { j N } ( Y ) = B _ { 3 } ^ { N } ( Y ) ; }
\end{array} \quad \left\{\begin{array}{l}
\varphi_{j 0}(Y)=-4 B_{3}^{-1}(Y)+B_{3}^{0}(Y) ; \\
\varphi_{j 1}(Y)=B_{3}^{-1}(Y)-\frac{1}{2} B_{3}^{0}(Y)+B_{3}^{1}(Y) ; \\
\varphi_{j i}(Y)=B_{3}^{i}(Y), \quad i=\overline{2, N-2} ; \\
\varphi_{j N-1}(Y)=B_{3}^{N-1}(Y)-\frac{1}{2} B_{3}^{N}(Y)+B_{3}^{N+1}(Y) ; \\
\varphi_{j N}(Y)=B_{3}^{N}(Y)-4 B_{3}^{N+1}(Y) .
\end{array}\right.\right.
\end{gathered}
$$

In the formulas (17) $B_{3}^{i}(i=\overline{-1, N+1})$ - the basis splines of the third order given by

$$
B_{3}^{i}(Y)=\frac{1}{6}\left\{\begin{array}{ll}
0, & -\infty<Y<Y_{i-2}, \\
(t)^{3} & Y_{i-2} \leq Y<Y_{i-1}, \\
-3 q^{3}+3 q^{2}+3 q+1, & Y_{i-1} \leq Y<Y_{i}, \\
3 q^{3}-6 q^{2}+4, & Y_{i} \leq Y<Y_{i+1}, \\
(1-q)^{3} & Y_{i+1} \leq Y<Y_{i+2}, \\
0, & Y_{i+2} \leq Y<\infty
\end{array} \quad q=\frac{Y-Y_{p}}{Y_{p+1}-Y_{p}}, \quad p=\overline{i-2, i+1}\right) .
$$

The equations are required to be satisfied in the collocation points $\xi_{k}, \quad k=\overline{0, N}$ $(N=2 s+1)$, which are chosen on the uniform lattice $\Delta: 0=Y_{0}<Y_{1}<\ldots<Y_{N}=1$ so, that $\xi_{2 l}=Y_{2 l}+t_{1} / N, \xi_{2 l+1}=Y_{2 l}+t_{2} / N, \xi_{2 l}, \xi_{2 l+1} \in\left[Y_{2 l}, Y_{2 l+1}\right](l=\overline{0, s})$. The points $t_{1}$ and $t_{2}$ are the roots of Legendre polynomial of the second order $t_{1,2}=1 / 2 \pm \sqrt{3} / 6$. Thus, in every interval $\left[Y_{2 l}, Y_{2 l+1}\right]$ there are two collocation nodes, and on the neighboring intervals $\left[Y_{2 l-1}, Y_{2 l}\right]$ and $\left[Y_{2 l+1}, Y_{2 l+2}\right]$ there are none.

The governing system of the linear ordinary differential equations with constant coefficients is presented in the following vector-matrix form:

$$
\frac{d \bar{R}}{d X}=A \bar{R}
$$

In the system (19) $\bar{R}=\bar{R}(X)=\left[\begin{array}{llllllllll}\bar{u} & \overline{\tilde{u}} & \bar{v} & \overline{\tilde{v}} & \bar{w} & \overline{\widetilde{w}} & \bar{\psi}_{X} & \overline{\widetilde{\psi}}_{X} & \bar{\psi}_{Y} & \overline{\widetilde{\psi}}_{Y}\end{array}\right]^{T}$ - vectorcolumn of size $10(N+1)$, the elements of which look like this:

$$
u_{i}^{\prime}(X)=\tilde{u}_{i}(X), \quad v_{i}^{\prime}(X)=\tilde{v}_{i}(X), \quad w_{i}^{\prime}(X)=\tilde{w}_{i}(X), \quad \psi_{X i}^{\prime}(X)=\tilde{\psi}_{X i}(X), \quad \psi_{Y i}^{\prime}(X)=\tilde{\psi}_{Y i}(X)
$$




$$
\begin{aligned}
& \bar{u}(X)=\left(\begin{array}{c}
u_{0} \\
u_{1} \\
\vdots \\
u_{N}
\end{array}\right), \quad \bar{v}(X)=\left(\begin{array}{c}
v_{0} \\
v_{1} \\
\vdots \\
v_{N}
\end{array}\right), \quad \bar{w}(X)=\left(\begin{array}{c}
w_{0} \\
w_{1} \\
\vdots \\
w_{N}
\end{array}\right), \quad \bar{\psi}_{X}(X)=\left(\begin{array}{c}
\psi_{X 0} \\
\psi_{X 1} \\
\vdots \\
\psi_{X N}
\end{array}\right), \quad \bar{\psi}_{Y}(X)=\left(\begin{array}{c}
\psi_{Y 0} \\
\psi_{Y 1} \\
\vdots \\
\psi_{Y N}
\end{array}\right) ; \\
& \overline{\widetilde{u}}(X)=\left(\begin{array}{c}
\tilde{u}_{0} \\
\tilde{u}_{1} \\
\vdots \\
\tilde{u}_{N}
\end{array}\right) ; \quad \overline{\widetilde{v}}(X)=\left(\begin{array}{c}
\tilde{v}_{0} \\
\tilde{v}_{1} \\
\vdots \\
\tilde{v}_{N}
\end{array}\right) ; \quad \overline{\widetilde{w}}(X)=\left(\begin{array}{c}
\tilde{w}_{0} \\
\tilde{w}_{1} \\
\vdots \\
\tilde{w}_{N}
\end{array}\right) ; \quad \tilde{\widetilde{\psi}}_{X}(X)=\left(\begin{array}{c}
\tilde{\psi}_{X 0} \\
\tilde{\psi}_{X 1} \\
\vdots \\
\tilde{\psi}_{X N}
\end{array}\right) ; \quad \overline{\widetilde{\psi}}_{Y}(X)=\left(\begin{array}{c}
\tilde{\psi}_{Y 0} \\
\tilde{\psi}_{Y 1} \\
\vdots \\
\tilde{\psi}_{Y N}
\end{array}\right) \text {. }
\end{aligned}
$$

In the formulas (19) $A=A(X, \xi, \omega)$ - the quadratic matrix of size 10, non-zero elements of which are presented as follows:

$$
\begin{aligned}
& A_{12}=A_{34}=A_{56}=A_{78}=A_{9,10}=E, \\
& A_{21}=\left(\begin{array}{lll}
\left.a_{11} E+a_{12} \Phi_{10}^{-1} \Phi_{12}\right), \quad A_{24}=a_{13} \Phi_{10}^{-1} \Phi_{21}, & A_{26}=a_{14} \Phi_{10}^{-1} \Phi_{30}, \quad A_{27}=a_{15} \Phi_{10}^{-1} \Phi_{42}, \\
A_{2,10}=a_{16} \Phi_{10}^{-1} \Phi_{51}, \quad A_{42}=a_{21} \Phi_{20}^{-1} \Phi_{11}, \quad A_{43}=a_{22} E+a_{23} \Phi_{20}^{-1} \Phi_{22}, \quad A_{45}=a_{24} \Phi_{20}^{-1} \Phi_{31}, \\
A_{48}=a_{25} \Phi_{20}^{-1} \Phi_{41}, \quad A_{49}=\Phi_{20}^{-1}\left(a_{26} \Phi_{50}+a_{27} \Phi_{52}\right), \quad A_{62}=a_{31} \Phi_{30}^{-1} \Phi_{10}, \quad A_{63}=a_{32} \Phi_{30}^{-1} \Phi_{21}, \\
A_{65}=a_{33} E+a_{34} \Phi_{30}^{-1} \Phi_{32}, \quad A_{68}=a_{35} \Phi_{30}^{-1} \Phi_{40}, \quad A_{69}=a_{36} \Phi_{30}^{-1} \Phi_{51}, \quad A_{81}=a_{41} \Phi_{40}^{-1} \Phi_{10}, \\
A_{86}=a_{42} \Phi_{40}^{-1} \Phi_{30}, \quad A_{87}=a_{43} E+a_{44} \Phi_{40}^{-1} \Phi_{42}, \quad A_{8,10}=a_{45} \Phi_{40}^{-1} \Phi_{51}, \quad A_{10,3}=a_{51} \Phi_{50}^{-1} \Phi_{20}, \\
A_{10,5}=a_{52} \Phi_{50}^{-1} \Phi_{31}, \quad A_{10,8}=a_{53} \Phi_{50}^{-1} \Phi_{41}, \quad A_{10,9}=a_{54} E+a_{55} \Phi_{50}^{-1} \Phi_{52} .
\end{array}\right.
\end{aligned}
$$

In the expressions (21) $E$ - identity matrix of size $N+1$; the quadratic matrix $\Phi_{j \alpha}(\xi)=\left[\varphi_{j i}^{(\alpha)}\left(\xi_{k}\right)\right](i, k=\overline{0, N}, j=\overline{1,5}, \alpha=\overline{0,2})$ looks like this:

$$
\Phi_{j \alpha}(\xi)=\left[\varphi_{j i}^{(\alpha)}\left(\xi_{k}\right)\right]=\left(\begin{array}{cccc}
\varphi_{j 0}^{(\alpha)}\left(\xi_{0}\right) & \varphi_{j 1}^{(\alpha)}\left(\xi_{0}\right) & \cdots & \varphi_{j N}^{(\alpha)}\left(\xi_{0}\right) \\
\varphi_{j 0}^{(\alpha)}\left(\xi_{1}\right) & \varphi_{j 1}^{(\alpha)}\left(\xi_{1}\right) & \cdots & \varphi_{j N}^{(\alpha)}\left(\xi_{1}\right) \\
\cdots & \cdots & \cdots & \cdots \\
\varphi_{j 0}^{(\alpha)}\left(\xi_{N}\right) & \varphi_{j 1}^{(\alpha)}\left(\xi_{N}\right) & \cdots & \varphi_{j N}^{(\alpha)}\left(\xi_{N}\right)
\end{array}\right) .
$$

The coefficients $a_{i j}$ in (21) are of such values:

$$
\begin{aligned}
& a_{11}=-\frac{a^{2} \omega^{2} I_{0}}{C_{11}}, \quad a_{12}=-\frac{C_{66}}{C_{11}}, \quad a_{13}=-\frac{C_{12}+C_{66}}{C_{11}}, \quad a_{14}=-\frac{a}{C_{11}}\left(C_{11} k_{1}+C_{12} k_{2}\right), \\
& a_{15}=a_{16}=-\frac{D_{66} k_{1}}{C_{11}} ; \quad a_{21}=-\frac{C_{12}+C_{66}}{C_{66}}, \quad a_{22}=\frac{a^{2}}{C_{66}}\left(K C_{44} k_{2}^{2}-\omega^{2} I_{0}\right), \quad a_{23}=-\frac{C_{22}}{C_{66}}, \\
& a_{24}=-\frac{a}{C_{66}}\left(D_{12} k_{1}^{2} k_{2}+D_{22} k_{2}^{3}+C_{12} k_{1}+C_{22} k_{2}+K C_{44} k_{2}\right), \quad a_{25}=\frac{D_{12} k_{2}}{C_{66}}, \\
& a_{26}=\frac{a^{2} k_{2}}{C_{66}}\left(\omega^{2} I_{2}-K C_{44}\right), \quad a_{27}=\frac{D_{22} k_{2}}{C_{66}} ; \quad a_{31}=\frac{a}{K C_{55}}\left(C_{11} k_{1}+C_{12} k_{2}\right)+a k_{1},
\end{aligned}
$$




$$
\begin{aligned}
& a_{32}=\frac{a}{K C_{55}}\left(C_{12} k_{1}+C_{22} k_{2}+K C_{44} k_{2}\right), \quad a_{33}=\frac{a^{2}}{K C_{55}}\left(C_{11} k_{1}^{2}+2 C_{12} k_{1} k_{2}+C_{22} k_{2}^{2}-\omega^{2} I_{0}\right), \\
& a_{34}=-\frac{C_{44}}{C_{55}}, \quad a_{35}=-a, \quad a_{36}=-\frac{a C_{44}}{C_{55}} ; \quad a_{41}=-\frac{a^{2} K C_{55} k_{1}}{D_{11}}, \\
& a_{42}=\frac{a}{D_{11}}\left(k_{2}^{2} D_{12}+K C_{55}\right)+a k_{1}^{2}, \quad a_{43}=\frac{a^{2}}{D_{11}}\left(K C_{55}-\omega^{2} I_{2}\right), \quad a_{44}=-\frac{D_{66}}{D_{11}}, \\
& a_{45}=-\frac{D_{12}+D_{66}}{D_{11}} ; \quad a_{51}=-\frac{a^{2} K C_{44} k_{2}}{D_{66}}, \quad a_{52}=\frac{a}{D_{66}}\left(D_{12} k_{1}^{2}+D_{22} k_{2}^{2}+K C_{44}\right), \\
& a_{53}=-\frac{D_{12}+D_{66}}{D_{66}}, \quad a_{54}=\frac{a^{2}}{D_{66}}\left(K C_{44}-\omega^{2} I_{2}\right), \quad a_{55}=-\frac{D_{22}}{D_{66}} .
\end{aligned}
$$

For all sides simply supported we have the following boundary conditions:

$$
B_{1,2}=\left(\begin{array}{lllllllllll}
O & \Phi_{10} & O & O & O & O & O & O & O & O \\
O & O & \Phi_{20} & O & O & O & O & O & O & O \\
O & O & O & O & \Phi_{30} & O & O & O & O & O \\
O & O & O & O & O & O & O & \Phi_{40} & O & O \\
O & O & O & O & O & O & O & O & \Phi_{50} & O
\end{array}\right) \text {, }
$$

where $O$-zero matrix of size $N+1 ; \Phi_{j 0}$ - nonconfluent quadratic matrix of size $N+1$. The problem (19), (24) is solved by the stable numerical method of the discrete orthogonalization [10] combined with the step-by-step search method.

Let us analyze the shallow shells with the following mechanical characteristics:

$$
\begin{aligned}
& a=b=1, \quad E_{x} / E_{y}=25, \quad G_{x y} / E_{y}=G_{x z} / E_{y}=0.5, \quad G_{y z} / E_{y}=0.2, \quad v_{x y}=0.25 ; \\
& a=b=1, \quad E_{x} / E_{y}=15, \quad G_{x y} / E_{y}=G_{x z} / E_{y}=0.5, \quad G_{y z} / E_{y}=0.5, \quad v_{x y}=0.25 .
\end{aligned}
$$

Table 1 presents lower nondimensionalized natural frequencies $\varpi$ of the simply supported cylindrical shallow shells with the material properties of the lamina given in (25). Shell thickness, radii of curvature and lamination scheme are also reported in Table 1 . The results are obtained using the proposed spline-collocation technique $(N+1=18)$ and the discrete orthogonalization method (100 orthogonalization points). Comparing our nondimensionalized natural frequencies with the 19-term Navier type solutions (expands the displacement field into double Fourier series) done by Reddy in [9], we can see less than $1 \%$ deviation in values.

Table 2 presents lower nondimensionalized natural frequencies $\varpi$ of the simply supported spherical shallow shells with the material properties of the lamina reported in (25). Shell thickness, radii of curvature and lamination scheme are also reported in Table 2. The results are obtained using the proposed spline-collocation technique $(N+1=18)$ and the discrete orthogonalization method (100 orthogonalization points) and compared to 19-term Navier type solutions (expands the displacement field into double Fourier series) done by Reddy in [9]. 
Table 1

Nondimensionalized natural frequencies of the cylindrical shallow shell

\begin{tabular}{|c|c|c|c|c|c|c|c|}
\hline \multirow{2}{*}{ Lamination scheme } & \multirow{2}{*}{$a / h$} & \multirow{2}{*}{ Method } & \multicolumn{5}{|c|}{$R / a$} \\
\cline { 3 - 8 } & & 5 & 10 & 20 & 50 & 100 \\
\hline \multirow{3}{*}{$0 / 90 / 0$} & \multirow{2}{*}{10} & Fourier & 12.207 & 12.173 & 12.166 & 12.163 & 12.163 \\
\cline { 3 - 9 } & & Proposed & 12.3046 & 12.2706 & 12.2627 & 12.2612 & 12.2609 \\
\cline { 3 - 8 } & \multirow{2}{*}{100} & Fourier & 20.332 & 16.625 & 15.556 & 15.244 & 15.198 \\
\cline { 3 - 8 } & & Proposed & 20.4944 & 16.7568 & 15.6901 & 15.3671 & 15.3201 \\
\hline \multirow{3}{*}{$0 / 90 / 90 / 0$} & \multirow{2}{*}{10} & Fourier & 12.267 & 12.236 & 12.230 & 12.228 & 12.227 \\
\cline { 3 - 8 } & & Proposed & 12.3649 & 12.3321 & 12.3277 & 12.3254 & 12.3252 \\
\cline { 2 - 8 } & \multirow{2}{*}{100} & Fourier & 20.361 & 16.634 & 15.559 & 15.245 & 15.199 \\
\cline { 3 - 8 } & & Proposed & 20.5238 & 16.7687 & 15.6843 & 15.3657 & 15.3192 \\
\hline
\end{tabular}

Table 2

Nondimensionalized natural frequencies of the spherical shallow shell

\begin{tabular}{|c|c|c|c|c|c|c|c|}
\hline \multirow{2}{*}{ Lamination scheme } & \multirow{2}{*}{$a / h$} & \multirow{2}{*}{ Method } & \multicolumn{5}{|c|}{$R / a$} \\
\cline { 3 - 8 } & & 2 & 3 & 4 & 5 & 10 \\
\hline \multirow{3}{*}{$0 / 90 / 0$} & \multirow{2}{*}{10} & Fourier & 13.382 & 12.731 & 12.487 & 12.372 & 12.215 \\
\cline { 3 - 8 } & & Proposed & 13.4897 & 12.8339 & 12.5861 & 12.4740 & 12.3145 \\
\cline { 3 - 8 } & \multirow{2}{*}{100} & Fourier & 68.075 & 47.265 & 36.971 & 30.993 & 20.347 \\
\cline { 3 - 8 } & & Proposed & 68.6189 & 47.6382 & 37.2633 & 31.2444 & 20.5139 \\
\hline \multirow{3}{*}{$0 / 90 / 90 / 0$} & \multirow{2}{*}{10} & Fourier & 13.447 & 12.795 & 12.552 & 12.437 & 12.280 \\
\cline { 3 - 8 } & & Proposed & 13.5545 & 12.8972 & 12.6519 & 12.5351 & 12.3756 \\
\cline { 2 - 8 } & \multirow{2}{*}{100} & Fourier & 68.294 & 47.415 & 37.082 & 31.079 & 20.380 \\
\cline { 3 - 8 } & & Proposed & 68.8370 & 47.8101 & 37.3754 & 31.3249 & 20.5473 \\
\hline
\end{tabular}

Table 3

Nondimensionalized natural frequencies of the shallow shell with lamination scheme 0/90/90/0

\begin{tabular}{|l|c|c|c|c|c|}
\hline \multirow{3}{*}{ Shell type } & \multirow{3}{*}{$a / h$} & Formulation and method & \multicolumn{3}{|c|}{$R / a$} \\
\cline { 3 - 5 } & & & 2 & 5 & 10 \\
\hline \multirow{4}{*}{ Cylindrical } & 10 & FSDT and Fourier & 11.3342 & 11.0316 & 10.9867 \\
\cline { 3 - 6 } & & CLT and Fourier & 12.5784 & 12.3270 & 12.2897 \\
\cline { 3 - 6 } & \multirow{3}{*}{100} & FSDT and proposed & 11.4261 & 11.1189 & 11.0678 \\
\cline { 3 - 6 } & & FSDT and Fourier & 35.1759 & 18.0992 & 13.9561 \\
\cline { 3 - 6 } & & CLT and Fourier & 35.1838 & 18.1107 & 13.9703 \\
\cline { 3 - 6 } & \multirow{3}{*}{10} & CLT and proposed & 35.4554 & 18.2470 & 14.0664 \\
\cline { 3 - 6 } & & FSDT and Fourier & 12.5718 & 11.2522 & 11.0428 \\
\cline { 3 - 6 } & & CLT and Fourier & 13.6975 & 12.5236 & 12.3397 \\
\cline { 3 - 6 } & \multirow{3}{*}{100} & FSDT and proposed & 12.6736 & 11.3435 & 11.2368 \\
\cline { 3 - 6 } & & FSDT and Fourier & 66.5695 & 29.3005 & 18.1175 \\
\cline { 3 - 6 } & & CLT and Fourier & 66.5774 & 29.3090 & 18.1290 \\
\cline { 3 - 6 } & FSDT and proposed & 67.1021 & 29.5382 & 18.2663 \\
\hline
\end{tabular}

Table 3 presents lower nondimensionalized natural frequencies $\varpi$ of the simply supported shallow shells with the lamination scheme 0/90/90/0 and technical characteristics 
given in (26). Shell thickness, radii of curvature and shell type are also reported in Table 3. The results are obtained from the present theory using the proposed spline-collocation technique $(N+1=18)$ and the discrete orthogonalization method (100 orthogonalization points) and compared to 19-term Navier type solutions (expands the displacement field into double Fourier series) done by Qatu in [8] who considered both classical laminate theory (CLT) and the firstorder shear deformation theory (FSDT).

Conclusions. In this paper first-order shear deformation theory was implemented for the free vibrations analysis of specially orthotropic symmetrically laminated cross-ply doublycurved shallow shells with constant thickness. The effect of the mechanical and geometric properties on the lower natural frequencies was analyzed. The comparative tables of results, obtained from both classical and refined formulations, using double Fourier series (19 terms), and the proposed method, were presented. Deviation between the values gained by means of the proposed technique and analytically, is not more than $1 \%$, which supports the possibility of using such an approach for the solution of the stated problems. It is shown, that when the thickness increases, the frequency of free vibrations of the spherical shells increases more sufficiently than for the cylindrical ones. Moreover, the frequency tends to decrease, when the radius of curvature increases, here the spherical shell is responding to it more sufficiently. The minimum difference between the vibration frequencies of thick cylindrical and spherical shells is observed, which tends to decrease greatly with the radius of curvature increase. When the shell stiffness decreases, the frequency of its natural vibration decreases too, the effect of thickness reduces as well, but the effect of the curvature becomes greater. For the thin shells the number of layers almost does not affect the frequencies, especially when the radius of curvature increases. It is clearly seen, that the classical laminate theory overestimates the vibration frequencies of thick cylindrical shells more than of the thick spherical shells, especially when the radius of curvature is smaller, but for the thin shells the results are almost identical to those, obtained from the refined formulation. Generally speaking, the frequencies of the spherical shells respond more effectively to the change of the mechanical and geometric properties, than for the cylindrical ones. The developed approach and the collected results make it possible to determine the expediency and high effectiveness of the spline-collocation and discrete orthogonalization methods for solving the problems of free vibrations of laminated shallow shells. Obtained solutions can be used as a guideline for further analysis of dynamic characteristics of such shells.

\section{References}

1. Kreja I.A. A literature review on computational models for laminated composite and sandwich panels. Central European Journal of Engineering, 2011, vol. 1, no. 1, pp. $59-80$.

2. Qatu M.S., Sullivan R.W., Wang W. Recent research advances on the dynamic analysis of composite shells: 2000-2009. Composite Structures, 2010, vol. 93, no. 1, pp. $14-31$.

3. Sayyad A.S., Ghugal Yu.M. On the free vibration analysis of laminated composite and sandwich plates: A review of recent literature with some numerical results. Composite Structures, 2015, vol. 129, pp. 177 201.

4. Grigorenko Ya.M. Bespalova E. I., Kitajgorodskij A.B., Shinkar' A.I. Svobodnye kolebaniya e'lementov obolochechnyx konstrukcij. Kiev, Naukova dumka, 1986. 172 p. [In Russian].

5. Hryhorenko Ya.M., Budak V.D., Hryhorenko O.Ya. Rozviazannia zadach teorii obolonok na osnovi dyskretno-kontynualnykh metodiv: navchalnyi posibnyk. Mykolaiv, Ilion, 2010. 294 p. [In Ukrainian].

6. Grigorenko Ya.M., A. T. Vasilenko Metody rascheta obolochek. T. 4. Teoriya obolochek peremennoj zhestkosti. Kiev: Naukova dumka, 1981. 544 p. [In Russian].

7. Mallick P.K. Fiber-reinforced composites materials manufacturing and design. Dearborn, Michigan, CRC Press, 3rd ed., 2008. 638 p.

8. Qatu M.S. Vibration of laminated shells and plates. San Diego, CA: Elsevier, 2004. 385 p.

9. Reddy J.N. Mechanics of laminated composite plates and shells: theory and analysis. CRC Press, 2nd ed., 2004. 854 p.

10. Godunov S.K. O chislennom reshenii kraevyx zadach dlya sistem linejnyx obyknovennyx differencial'nyx uravnenij. Uspexi matematicheskix nauk, 1961, vol. 16, no. 3, pp. 171 - 174 [In Russian]. 


\title{
Список використаної літератури
}

1. Kreja, I.A. A literature review on computational models for laminated composite and sandwich panels [Text] / I.A. Kreja // Central European Journal of Engineering, 2011. - T. 1, № 1. - P. 59 - 80.

2. Qatu, M.S. Recent research advances on the dynamic analysis of composite shells: 2000 - 2009 [Text] / M.S. Qatu, R.W. Sullivan, W. Wang // Composite Structures, 2010. - T. 93, № 1. - P. 14 - 31.

3. Sayyad, A.S. On the free vibration analysis of laminated composite and sandwich plates: A review of recent literature with some numerical results [Text] / A.S. Sayyad, Yu.M. Ghugal // Composite Structures, 2015. - 129. - P. $177-201$.

4. Свободные колебания элементов оболочечных конструкций [Текст] / Я.М. Григоренко, Е.И. Беспалова, А.Б. Китайгородский, А.И. Шинкарь. - К. : Наук. думка, 1986. - 172 с.

5. Григоренко, Я.М. Розв'язання задач теорії оболонок на основі дискретно-континуальних методів: навчальний посібник [Текст] / Я.М. Григоренко, В.Д. Будак, О.Я. Григоренко. - Миколаїв : Іліон, 2010. -294 c.

6. Григоренко, Я.М. Методы расчета оболочек. Т. 4. Теория оболочек переменной жесткости [Текст] / Я.М. Григоренко, А.Т. Василенко. - Киев : Наук. думка, 1981. - 544 с.

7. Mallick, P.K. Fiber-reinforced composites materials manufacturing and design [Text] / P.K Mallick. Dearborn, Michigan, CRC Press, 3rd ed., 2008. - 638 p.

8. Qatu, M.S. Vibration of laminated shells and plates [Text] / M.S Qatu. - San Diego, CA: Elsevier, 2004. $385 \mathrm{p}$.

9. Reddy, J.N. Mechanics of laminated composite plates and shells: theory and analysis [Text] / J.N Reddy. CRC Press, 2nd ed., 2004. - 854 p.

10. Годунов, С.К. О численном решении краевых задач для систем линейных обыкновенных дифференциальных уравнений [Текст] / С.К. Годунов // Успехи математических наук, 1961. - Т. 16, № 3. - C. 171 - 174 .

\section{УДК 539.3}

\section{МЕТОД СПЛАЙН-КОЛОКАЦІї ДЛЯ ВИЗНАЧЕННЯ ВІЛЬНИХ КОЛИВАНЬ ПОЛОГИХ ШАРУВАТИХ ОБОЛОНОК}

\section{Олег Павленко}

\author{
Тернопільський начіональний технічний університет імені Івана Пулюя, \\ Тернопіль, Україна
}

Резюме. У рамках теорії Міндліна досліджено вільні коливання перехресно-щарових двоопуклих пологих оболонок постійної товщини з прямокутним планом. Вважається, що шари виготовлені 3 ортотропного матеріалу і розміщені симетрично відносно серединної поверхні, а головні напрямки пружності кожного шару співпадають з координатними лініями. Головну увагу приділено шарнірно закріпленим по контуру еліптичним та параболічним пологим оболонкам зі згаданими властивостями $i$ схемою розтушування шарів 0/90/0 і 0/90/90/0. Виведену двовимірну систему диференціальних рівнянь відносно переміщень і кутів повороту зведено до одновимірної задачі на власні значення методом сплайнапроксимації розв 'язків у одному з координатних напрямків із використанням базисних сплайнів третього порядку. Останню розв'язано стійким чисельним методом дискретної ортогоналізаиії у поєднанні $з$ методом покрокового пошуку. Розв'язувальну систему рівнянь з відповідними граничними умовами представлено у векторно-матричній формі. У порівняльних таблицях наведено нижчі частоти вільних коливань зазначених оболонок із різними геометричними й механічними параметрами, отримані запропонованим методом. Останні зіставлено з результатами, представленими в роботах інших авторів. За результатами розв'язання задач даного класу можна дослідити залежності вільних коливань перехресно-шарових пологих прямокутних у плані оболонок від геометричних $і$ механічних параметрів, а також виявити закономірності у розподілі частот. Отримані обезрозмірені частоти можуть бути використані в працяя для оцінювання міциності й надійності елементів конструкцій. Слід зазначити, щцо інформація про динамічні характеристики шаруватих пологих оболонок є важливим етапом оцінювання міиності та надійності оболонкової системи в иілому, виготовленої з сучасних композитних матеріалів. Отже, розробення ефективного підходу на основі чисельних методів для розв'язання таких задач у сучасних програмних комплексах є вимогою сьогоденного технічного прогресу. Міндлін

Ключові слова: вільні коливання, шарувата полога оболонка, метод сплайн-колокації, теорія 